\title{
Characterization of Gibberellin Producing Rhizobacteria Isolated from Soil Forest in Banten
}

\author{
(Karakteristik Rizobakteri Penghasil Giberelin yang Diisolasikan dari Tanah \\ Hutan di Banten) \\ Hadi Susilo ${ }^{1}$, Nisa Rachmania Mubarik ${ }^{2 *}$ Triadiati $^{2}$ \\ ${ }^{1}$ Program Studi Pascasarjana Bioteknologi, Institut Pertanian Bogor, Bogor 16680, Indonesia \\ ${ }^{2}$ Departemen Biologi, Fakultas MIPA, Institut Pertanian Bogor, Bogor 16680, Indonesia
}

Received : 4 January 2015 Accepted: 30 March 2015

*Corresponding author: Dr Nisa Rachmania Mubarik, M.Si; Departemen Biologi, Jln. Agatis, Bogor 16680; E-mail: nrachmania@ipb.ac.id

\section{ABSTRACT}

Gibberellin is plant growth regulator that stimulates cell elongation, seed germination, flowering, and fruit ripening. This study was conducted to isolate, identify, and optimize growth media for gibberellins producing- rhizobacteria isolated from rhizosphere soil of "keruing" (Dipterocarpus sp.) tree in forest research Carita, Pandeglang, Banten. Eight bacterial isolates were obtained and all produced gibberellin. The BC2 isolate produced the highest of gibberellin $\left(0.897 \mathrm{mg} \mathrm{mL}^{-1}\right)$ and then selected for identification based on physiology, molecular character, and effects of growth media with variation of temperature, $\mathrm{pH}$, and light. The result of physiological test indicated that $\mathrm{BC} 2$ isolate does not produce indole, positive on urease and oxidative carbohydrate. The phylogenetic analysis showed that BC2 isolate is belonged to Stenotrophomonas maltophilia with $98 \%$ similarity level. The optimation of growth media indicated that the growth of $\mathrm{BC} 2$ isolate was optimum at $30^{\circ} \mathrm{C}, \mathrm{pH} 7$, and dark condition.

Keywords: Plant growth regulator, rhizobacteria, Stenotrophomonas maltophilia.

\section{ABSTRAK}

Giberelin adalah zat pengatur tumbuh yang memacu pemanjangan sel, perkecambahan biji, pembungaan, dan pemasakan buah. Tujuan penelitian ini untuk mengisolasi, identifikasi, dan optimasi media pertumbuhan rizobakteri penghasil giberelin dari tanah rizosfer pohon keruing (Dipterocarpus sp.) di hutan penelitian Carita, Pandeglang, Banten. Delapan isolat rizobakteri menghasilkan giberelin, tertinggi pada isolat BC2 yaitu $0.897 \mathrm{mg} \mathrm{mL}^{-1}$. Isolat BC2 diseleksi untuk diidentifikasi berdasarkan karakter fisiologi, molekuler, dan optimasi media pertumbuhan dengan perlakuan suhu, $p H$, dan kondisi cahaya. Uji fisiologi menunjukkan bahwa isolat BC2 negatif pada uji indol, urease positif, dan karbohidrat oksidatif. Analisis filogenetik menunjukkan isolat BC2 sebagai Stenotro- 
phomonas maltophilia dengan tingkat kesamaan $98 \%$. Hasil optimasi media tumbuh menunjukkan bahwa isolat BC2 tumbuh optimum pada suhu $30^{\circ} \mathrm{C}, \mathrm{pH}$ 7, dan kondisi gelap.

Kata kunci: Zat pengatur tumbuh, rizobakteri, Stenotrophomonas maltophilia

\section{PENDAHULUAN}

Giberelin adalah produk penting dalam bioteknologi yang mempunyai nilai ekonomi tinggi, banyak digunakan dalam bidang pertanian, pembibitan, pemeliharaan anggur, dan industri bir (Bandelier \& Renaud 1997). Giberelin adalah senyawa organik kelompok diterpenoid, tersusun dari unit isopren yang terdiri atas 5 atom karbon dengan struktur cincin tulang hidrokarbon (giberelin). Biosintesis giberelin melalui jalur asam mevalonat (Gomi \& Matsuoka 2003).

Giberelin pada tumbuhan berfungsi sebagai berikut: mematahkan dormansi (Zeiger \& Taiz 2006), meningkatkan pembungaan (Ribeiro \& Cardoso 2012; Goldberg-Moeller et al. 2013), memacu proses perkecambahan biji, dan pemanjangan sel (Fernie \& Willmitzer 2001; Miransari \& Smith 2014). Giberelin dihasilkan oleh tanaman, fungi (MacMillan 2002), dan bakteri (Bottini et al. 1989; Atzorn et al. 1998).

Penelitian mengenai isolasi, karakterisasi dan pengaruh media pertumbuhan rizobakteri indigenous penghasil giberelin di Indonesia sangat sedikit. Hutan Carita, di Pandeglang Banten adalah hutan penelitian yang didominasi oleh pohon keruing (Dipterocarpus sp.) yang belum banyak dieksplorasi keanekaragaman hayatinya, khususnya mikrob penghasil giberelin. Sehubungan dengan hal tersebut maka perlu dilakukan penelitian mengenai rizobakteri penghasil giberelin asal tanah hutan di Carita, Banten. Tujuan penelitian ini untuk mengisolasi rizobakteri penghasil giberelin, mengidentifikasikan isolat rizobakteri berdasarkan karakter morfologi, fisiologi, dan secara molekuler berdasarkan gen $16 \mathrm{~S} \mathrm{r}$ RNA, serta mengetahui pengaruh suhu, $\mathrm{pH}$, dan kondisi cahaya terhadap pertumbuhan sel rizobakteri dan produksi giberelin.

\section{METODOLOGI}

Bahan yang digunakan pada penelitian ini ialah sampel tanah yang berasal dari rizosfer pohon keruing (Dipterocarpus sp.) di hutan penelitian Carita, Pandeglang, Banten (06 ${ }^{\circ}$ ' $-06^{\circ} 14^{\prime} \mathrm{LS}$ dan $105^{\circ} 50-105^{\circ} 55^{\prime} \mathrm{BT}$ ).

\section{Pengambilan Sampel Tanah}

Pengambilan sampel tanah menggunakan metode Composite sampling (Hyde et al. 2009). Sampel tanah diambil dari 10 titik pengambilan sampel secara acak, diambil pada kedalaman 10$15 \mathrm{~cm}$, dari tanah yang menempel pada bulu-bulu akar tanaman. Tanah kemudian dikompositkan, diambil sebanyak $1 \mathrm{~kg}$ tanah untuk analisis rizobakteri penghasil giberelin.

\section{Isolasi Rizobakteri Penghasil Giberelin dari Tanah}

Rizobakteri penghasil giberelin diisolasi mengggunakan media seleksi: Trypticase Soy Agar (TSA), King's B, Nitrogen Free-Base (NFB), dan Lactose Glucose Induce (LGI). King's B Medium memiliki komposisi: protease pepton $20 \mathrm{~g}, \mathrm{~K}_{2} \mathrm{HPO}_{4} 1.5 \mathrm{~g}, \mathrm{MgSO}_{4} .7 \mathrm{H}_{2} \mathrm{O} 1.5$ 
g, gliserol $15 \mathrm{~mL}$, agar-agar bacto $20 \mathrm{~g}, \mathrm{~K}_{2} \mathrm{HPO}$ $1.5 \mathrm{~g}$, dilarutkan dalam akuades $1000 \mathrm{~mL}$. NFB Medium dengan komposisi: asam malat $5 \mathrm{~g}, \mathrm{KOH}$ $4 \mathrm{~g}, \mathrm{~K}_{2} \mathrm{HPO}_{4} 0.5 \mathrm{~g}, \mathrm{FeSO}_{4} 0.05 \mathrm{~g}, \mathrm{MgSO}_{4} .7 \mathrm{H}_{2} \mathrm{O}$ $0.01 \mathrm{~g}, \mathrm{MgSO}_{4} .7 \mathrm{H}_{2} \mathrm{O} 0.1 \mathrm{~g}, \mathrm{NaCl} 0.02 \mathrm{~g}, \mathrm{CaCl}$ $0.01 \mathrm{~g}, \mathrm{Na}_{2} \mathrm{Mo.O}_{4} 0.002 \mathrm{~g}$, Bromothymol Blue (BTB) $0.5 \%$ (alk) $2 \mathrm{~mL}$, agar-agar bacto 1.75 g, pH 6.8 dilarutkan dalam akuades 1000 mL, dan LGI Medium memiliki komposisi: sukrosa $20 \mathrm{~g}, \mathrm{~K}_{2} \mathrm{HPO}_{4} 0.015 \mathrm{~g}, \mathrm{KH}_{2} \mathrm{PO}_{4} 0.019 \mathrm{~g}, \mathrm{CaCl}_{2}$ $0.20 \mathrm{~g}, \mathrm{Mg}_{3} \mathrm{O}_{4} 0.002 \mathrm{~g}, \mathrm{Na}_{2} \mathrm{MoO}_{4} 0.0192 \mathrm{~g}$, $\mathrm{FeCl}_{2} 0.019 \mathrm{~g}, \mathrm{CaCO}_{3} 0.10 \mathrm{~g}$, agar-agar bacto $15 \mathrm{~g}$, dilarutkan dalam akuades $1000 \mathrm{~mL}$, dan $2 \mathrm{~mL}$ larutan Bromothymol Blue (BTB), dan dikocok dengan kecepatan 120 rpm. Selanjutnya diinkubasi pada suhu ruang $\pm 25^{\circ} \mathrm{C}$, selama 1-3 hari. Koloni yang tumbuh pada media disubkulturkan pada media seleksi yang sama sampai diperoleh isolat murni.

\section{Analisis Kemampuan Produksi Giberelin}

Isolat rizobakteri ditumbuhkan pada media cair TSB selama 24 jam pada suhu ruang $\pm 25^{\circ} \mathrm{C}$ dan dikocok dengan kecepatan $120 \mathrm{rpm}$. Sampel kultur isolat rizobakteri ditimbang $5 \mathrm{~g}$, ditambahkan $100 \mathrm{~mL}$ pelarut campuran metanol:kloroform: $2 \mathrm{~N}$ amonium hidroksida $(12: 5: 3 \mathrm{v} / \mathrm{v} / \mathrm{v})$. Selanjutnya sampel dan pelarut ditambahkan $22.4 \mathrm{~mL}$ air steril, didiamkan dalam corong pemisah selama 24 jam sampai terjadi pemisahan 2 fase lapisan cairan. Lapisan cair kloroform dibuang, $\mathrm{pH}$ fase cair ekstrak diatur $\mathrm{pH} 2.5$ dengan menggunakan larutan $5 \mathrm{~N} \mathrm{HCl}$ atau $1 \mathrm{~N} \mathrm{NaOH}$. Hasil ekstraksi larutan ditambahkan dengan $15 \mathrm{~mL}$ etil asetat sampai 3 kali, didiamkan selama 15 menit sampai terjadi pemisahan 2 lapisan cairan ekstrak, lapisan ekstrak yang mengandung etil asetat kemudian dievaporasi dengan rotaroevaporator
(Buchi Instruments) pada suhu $65^{\circ} \mathrm{C}$. Ekstrak hasil evaporasi kemudian dilarutkan dalam metanol $10 \mathrm{~mL}$. Larutan standar giberelin dan sampel hasil ekstraksi, dianalisis kandungan giberelin (Unyayar 1996) dengan menggunakan spektrofotometer (Shimadzu Pharmaspec 1700) dengan $\lambda 263 \mathrm{~nm}$.

\section{Uji Hipersensitivitas pada Daun Tembakau}

Uji hipersensitif dilakukan pada daun tembakau (Nicotiana tabacum L.) dewasa umur 3 bulan (Vanneste et al. 1990). Isolat bakteri ditumbuhkan di media seleksi TSB, LGI, dan King's B cair (107 sel/ mL). Bakteri Pseudomonas syringae digunakan sebagai kontrol positif karena bersifat patogen pada tanaman, dengan gejala nekrosis pada daun, sedangkan air dan media sebagai kontrol negatif. Sebanyak $200 \mu \mathrm{L}$ dari kultur bakteri uji, kontrol positif, dan kontrol negatif, kemudian disuntikkan dengan menggunakan syringe tanpa jarum di permukaan bawah daun tembakau. Gejala hipersensitif diamati setelah 48 jam penyuntikan.

\section{Identifikasi dan Karakterisasi Isolat Bakteri}

Isolat rizobakteri terpilih dikarakterisasi berdasarkan ciri-ciri morfologi dan fisiologi mengikuti Bergey's Manual of Determintive Bacteriology (Palleroni 1984). Identifikasi bakteri berdasarkan ciri-ciri fisiologi menggunakan kit API 20NE (bioMerieux, Durham, USA). Identifikasi secara molekuler dilakukan berdasarkan gen $16 \mathrm{~S}$ rRNA. Isolat rizobakteri $\mathrm{BC} 2$ menumbuhkan pada medium Trypticase Soy Broth (TSB) selama 24 jam. Ekstraksi DNA Isolat BC2 mengikuti prosedur Presto ${ }^{\mathrm{TM}}$ Mini gDNA Bacteria Kit (Geneaid). DNA hasil ekstraksi diukur konsentrasi dan 
kemurniannya dengan menggunakan NanoDrop 2000 spektofotometer (Thermo Scientific, Wilmington, DE, USA). DNA hasil ekstraksi dijadikan cetakan. Amplifikasi menggunakan mesin Polymerase Chain Reaction (PCR) (EBSCO) dengan primer 67f (5'-CAG GCC TAA CAC ATG CAA GTC-3') dan 1387r (5'-GGG CGG WGT GTA CAA GGC-3') (Marchesi et al. 1998). Total volume untuk PCR yaitu $25 \mu \mathrm{L}$ terdiri atas: $12.5 \mu \mathrm{L}$ GoTag Green Master Mix 2X (Promega, Madison, W1, USA), $2.5 \mu \mathrm{L}$ primer $63 \mathrm{f}$ dan $1387 \mathrm{r}$ (10 pmol), $6.5 \mu \mathrm{L}$ Nuclease Free Water dan $1 \mu \mathrm{L}$ DNA template. Tahap PCR yang dilakukan yaitu: predenaturation $\left(95^{\circ} \mathrm{C}, 5\right.$ menit), denaturation $\left(95^{\circ} \mathrm{C}, 1\right.$ menit), annealing $\left(55^{\circ} \mathrm{C}, 1\right.$ menit), elongation $\left(72^{\circ} \mathrm{C}, 1.5\right.$ menit), dan extension $\left(72^{\circ} \mathrm{C}, 5\right.$ menit) dengan total sebanyak 30 siklus. Produk hasil PCR dielektroforesis dengan $1 \%$ $(\mathrm{w} / \mathrm{v})$ gel agarosa dengan voltase $80 \mathrm{~V}$ selama 45 menit, hasil elektroforesis diamati dengan menggunakan UV transiluminator GelDoc (Labquip) dengan pewarna Ethidium Bromida (EtBr). Penentuan urutan nukleotida dilakukan di Laboratorium $1^{\text {st }}$ Base PT Genetika Science, Singapura dengan mengirimkan sampel DNA isolat. Data sekuen DNA selanjutnya dilakukan BLASTN (Basic Local Alignment Search Tool Nucleotide) dengan data genom di GenBank kemudian disejajarkan menggunakan program MEGA 5.05. (MegaSoftware, Inc, Arizona, USA). Konstruksi pohon filogenetik dibuat dengan metode Neighbour Joining (NJ) (Altschul et al. 1997).

Pengaruh Suhu, pH dan Kondisi Cahaya Terhadap Pertumbuhan Sel dan Produksi

\section{Giberelin}

Pengaruh faktor lingkungan terhadap pertumbuhan sel dan produksi giberelin isolat terpilih diukur secara berurutan dan bertahap dengan parameter meliputi: suhu inkubasi media pertumbuhan, diatur pada suhu $25^{\circ} \mathrm{C}$, $30^{\circ} \mathrm{C}, 35^{\circ} \mathrm{C}$, dan $40^{\circ} \mathrm{C}$, $\mathrm{pH}$ media pertumbuhan diatur menggunakan bufer sitrat fosfat 0.2 $\mathrm{M}$ untuk pH 5 dan bufer fosfat $0.2 \mathrm{M}$ untuk $\mathrm{pH}$ 6, 7, 8; kondisi inkubasi cahaya gelap dan terang, kondisi gelap dilakukan dengan penutup aluminium foil dan kondisi terang pada cahaya ruang.

\section{Analisis Data}

Data hasil penelitian dianalisis dengan uji sidik ragam menggunakan software SAS 9.1.3 (SAS Institut, Cary, NC, USA).

\section{HASIL}

\section{Isolat Rizobakteri Penghasil Giberelin}

Dari isolasi bakteri sampel tanah rizosfer dari hutan penelitian vegetasi tanaman keruing di Hutan Penelitian Carita, Kabupaten Pandeglang, Banten menggunakan media seleksi TSA, NFB, LGI, dan King's B diperoleh 8 isolat bakteri, yaitu: $\mathrm{BC} 1, \mathrm{BC} 2, \mathrm{BC} 3$ tumbuh di media TSA, BC4, BC5, BC6 tumbuh di media LGI, BC7 dan BC8 tumbuh di media King's B, sedangkan dari media NBF tidak diperoleh isolat rizobakteri (Tabel 1).

\section{Kadar Giberelin Isolat Rizobakteri}

Analisis kadar giberelin 8 isolat rizobakteri, menunjukkan bahwa semua isolat rizobakteri mempunyai kemampuan untuk menghasilkan giberelin. Isolat $\mathrm{BC} 2$ menghasilkan giberelin tertinggi senilai 0.897 $\mathrm{mg} \mathrm{mL}^{-1}$ sedangkan isolat $\mathrm{BC} 4$ menghasilkan giberelin terendah senilai $0.220 \mathrm{mg} \mathrm{mL}^{-1}$ 
Curr. Biochem. 2 (1): 32 - 41

Tabel 1 Morfologi isolat rizobakteri rizosfer pohon keruing

\begin{tabular}{lccccccc}
\hline \multirow{2}{*}{ Media Seleksi } & \multirow{2}{*}{ Isolat } & Bentuk & Tepi & Elevasi & Warna & \multirow{2}{*}{ Gram } & \multirow{2}{*}{ Bentuk Sel } \\
\hline \multirow{2}{*}{ TSA } & BC1 & tak teratur & berombak & Rata & Putih & - & batang \\
& BC2 & Bundar & utuh & cembung & Hijau & - & batang \\
& BC3 & Bundar & utuh & Rata & Putih & - & batang \\
\multirow{2}{*}{ LG1 } & BC4 & konsentris & utuh & cembung & Hijau & + & batang \\
& BC5 & Bundar & licin & cembung & kuning & + & batang \\
\multirow{4}{*}{ King's B } & BC6 & Bundar & licin & cembung & Hijau & + & bulat \\
& BC7 & Bundar & licin & cembung & kuning & - & bulat \\
& BC8 & Bundar & licin & cembung & Hijau & - & bulat \\
\hline
\end{tabular}

(Gambar 1).

\section{Hipersensitivitas Isolat Rizobakteri Pada Daun Tembakau}

Hasil uji hipersensitivitas menunjukkan daun yang diinjeksi dengan Pseudomonas syringae mengalami gejala hipersensitif yang ditunjukkan dengan perubahan warna daun dari warna hijau menjadi kuning (Gambar 2). Hasil pengamatan setelah 48 jam masa inkubasi setelah penyuntikan, daun tembakau yang diberikan perlakuan kultur isolat $\mathrm{BC} 7$ dan $\mathrm{BC} 8$ menunjukkan gejala hipersensitif pada daerah penyuntikan, sedangkan 6 isolat lainnya tidak menunjukkan gejala hipersensitif (Tabel 2).

\section{Karakteristik Isolat BC2}

Isolat $\mathrm{BC} 2$ dipilih untuk uji lebih lanjut karena tidak menunjukkan gejala hipersensitif dan menghasilkan giberelin yang lebih tinggi di antara isolat lainnya. Identifikasi isolat BC2 didasarkan pada karakter fisiologi dan reaksi kimia yang terjadi dalam metabolisme bakteri (Tabel 3).

Hasil amplifikasi dari gen penyandi 16S rRNA pada gel agarosa $0.8 \%$ menghasilkan produk pita DNA dengan ukuran \pm 1300 pasang basa (Gambar 3). Hasil Analisis sekuen gen 16S rRNA menunjukkan bahwa isolat BC2 termasuk ke dalam genus Stenotrophomonas dengan nilai kesamaan $98 \%$ (Tabel 4).

Hasil konstruksi pohon filogenetik

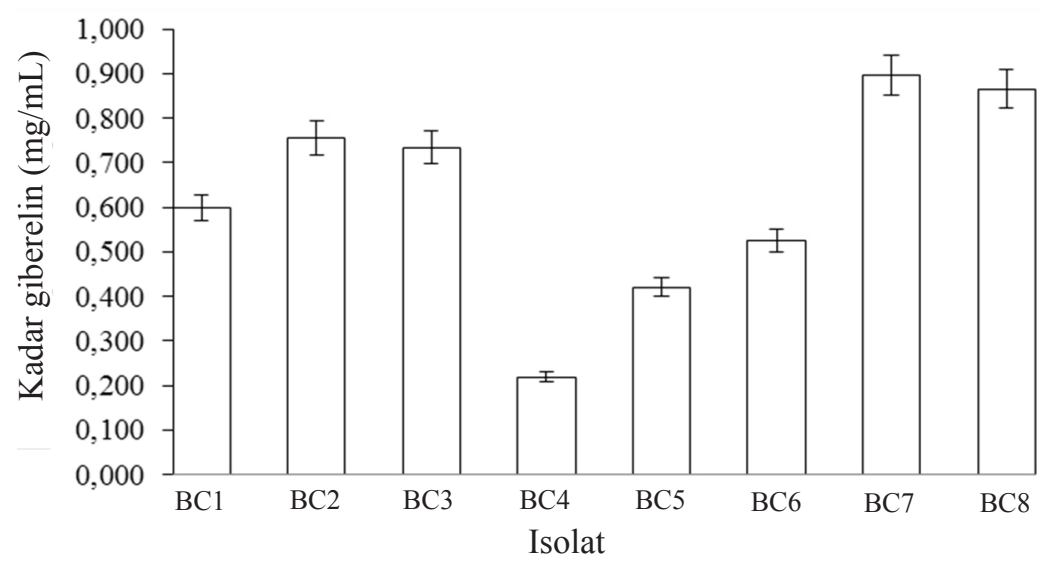

Gambar 1 Kadar giberelin yang dihasilkan isolat rizobakteri asal rizosfer pohon keruing (Dipterocarpus sp.). 
Tabel 2 Uji hipersensitivitas isolat rizobakteri pada daun tembakau

\begin{tabular}{cc}
\hline $\begin{array}{c}\text { Isolat } \\
\text { rizobakteri }\end{array}$ & $\begin{array}{c}\text { Hasil uji } \\
\text { hipersensitivitas }\end{array}$ \\
\hline $\mathrm{BC} 1$ & - \\
$\mathrm{BC} 2$ & - \\
$\mathrm{BC} 3$ & - \\
$\mathrm{BC} 4$ & - \\
$\mathrm{BC} 5$ & - \\
$\mathrm{BC} 6$ & - \\
$\mathrm{BC} 7$ & + \\
$\mathrm{BC} 8$ & + \\
\hline
\end{tabular}

menunjukkan bahwa isolat $\mathrm{BC} 2$ berada dalam satu clade dengan Stenotrophomonas maltophilia galur KC849451 (No aksesi KF839451.1) (Gambar 4).

\section{Suhu Optimum Terhadap Pertumbuhan Sel dan Produksi Giberelin}

Hasil perlakuan suhu terhadap media pertumbuhan isolat BC2 menunjukkan bahwa pada suhu $25^{\circ} \mathrm{C}$, dihasilkan kadar giberelin terendah sebesar $1.546 \mathrm{mg} \mathrm{mL}^{-1}$, sedangkan pada suhu $30^{\circ} \mathrm{C}$ dihasilkan kadar giberelin tertinggi sebesar $3.270 \mathrm{mg} \mathrm{mL}^{-1}$ (Gambar 5 ).

\section{pH Optimum Media Tumbuh untuk Produksi}

\section{Giberelin}

Hasil optimasi media dengan perlakuan

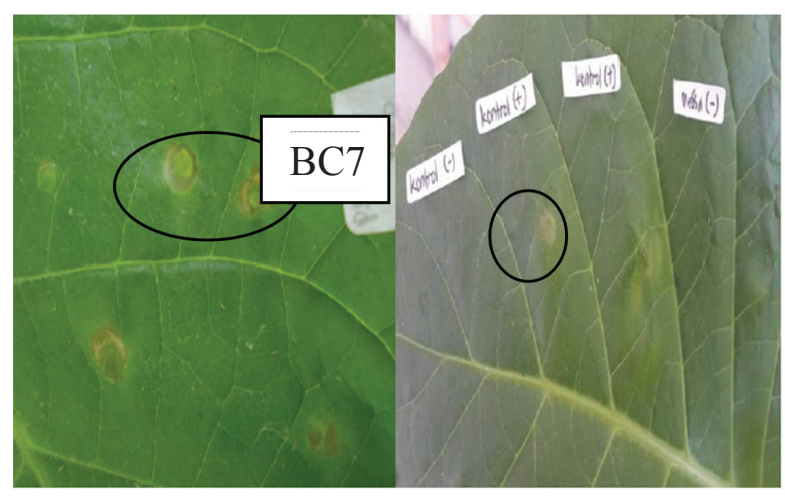

Gambar 2 Gejala hipersensitivitas BC7 pada tembakau.

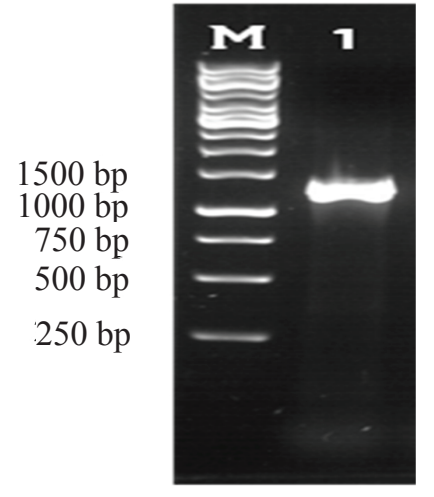

Gambar 3 Pita gen 16S rRNA berukuran \pm 1300 bp isolat $\mathrm{BC} 2$ (1), $\mathrm{M}=$ Marker $1 \mathrm{~kb}$.

$\mathrm{pH}$ menunjukkan bahwa pada $\mathrm{pH} 5$ produksi giberelin terendah dengan nilai $1.084 \mathrm{mg} \mathrm{mL}^{-1}$, sedangkan pada $\mathrm{pH} 7$ produksi giberelin tertinggi dengan nilai $3.270 \mathrm{mg} \mathrm{mL}^{-1}$ (Gambar 6).

\section{Pengaruh Cahaya Terhadap Produksi Giberelin}

Pertumbuhan isolat $\mathrm{BC} 2$ pada suhu $30{ }^{\circ} \mathrm{C}$ dan pH 7 menunjukkan bahwa kondisi gelap (tabung ditutup alumunium foil) menghasilkan produk giberelin yang lebih tinggi dibandingkan dengan kondisi terang (tabung tidak ditutup alumunium foil). Produksi giberelin oleh isolat BC2 pada kondisi gelap senilai $1.841 \mathrm{mg} \mathrm{mL}^{-1}$ lebih tinggi dibandingkan kondisi terang senilai $0.821 \mathrm{mg} \mathrm{mL}^{-1}$ (Tabel 5).

Tabel 3 Karakteristik isolat rizobakteri BC2

\begin{tabular}{lc}
\hline \multicolumn{1}{c}{ Pengujian } & Hasil uji fisiologi \\
\hline Metil merah & Negatif \\
$\mathrm{H}_{2} \mathrm{~S}$ & Negatif \\
Urease & Positif \\
Indol & Negatif \\
Nitrat & Positif \\
Metabolisme & Oksidatif \\
karbohidrat & \\
\hline
\end{tabular}




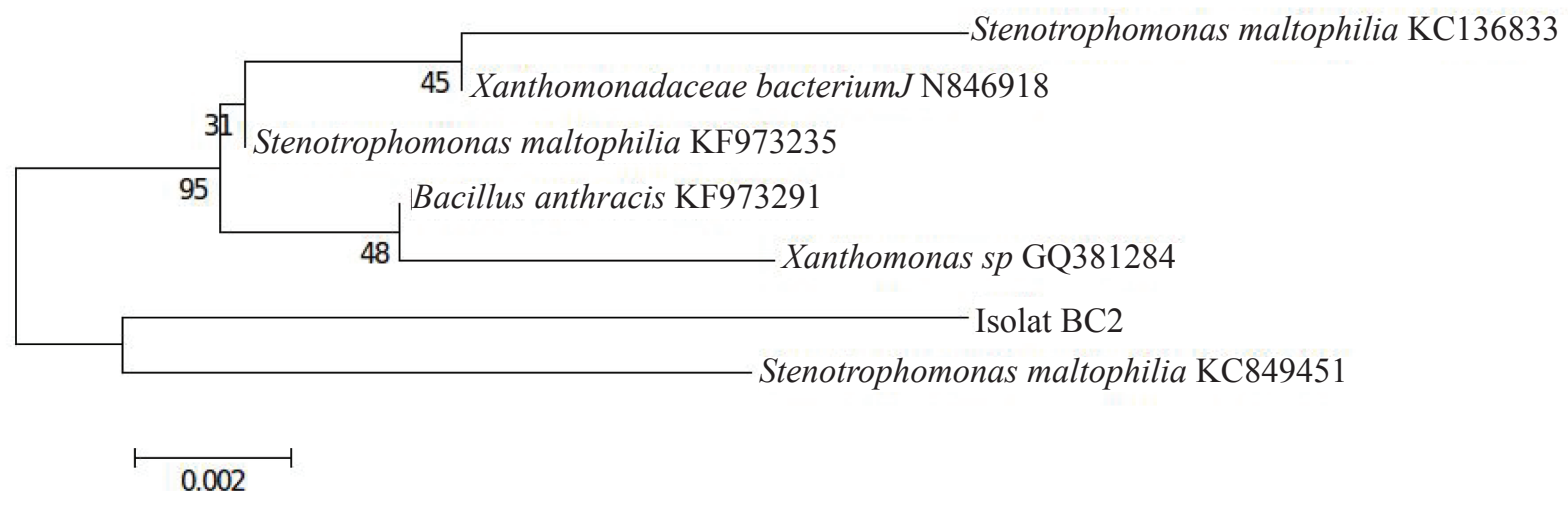

Gambar 4 Konstruksi pohon filogenetik isolat BC2 dengan metode Neighbor-Joining dengan nilai ulangan bootstrap 1000 kali.

\section{PEMBAHASAN}

Rizobakteri dapat tumbuh di sekitar rizosfer perakaran tumbuhan. Namun di laboratorium, hanya isolat yang dapat dikulturkan yang dapat tumbuh dan berhasil diisolasi. Pada penelitian ini tidak didapatkan isolat yang tumbuh pada media Nitrogen FreeBase (NFB) yang diduga tidak ada sumber nitrogen seperti pada media Trypticase Soy Agar (TSA), Lactose Glucose Induce (LGI) dan King's B. Di alam eksudat perakaran merupakan sumber nutrisi yang berperan sebagai penghambat dan stimulator terhadap keragaman populasi rizobakteri (Lebuhn et al. 1997) menjadi pembeda, penentu keragaman, dan jumlah populasi pada rizosfer tanaman
(Broekling 2008; Piromyou et al. 2011; Gunes et al. 2013).

Sebanyak delapan isolat rizobakteri yang diisolasi dari tanah rizosfer pohon keruing menghasilkan giberelin (Gambar 1) dengan kemampuan yang berbeda dalam menghasilkan giberelin. Kemampuan isolat rizobakteri dalam menghasilkan giberelin tidak sama (Cappelari et al. 2013) hal ini dipengaruhi oleh karakteristik biokimia dan faktor lingkungan (Ahmad 2008 et al.; Kumar 2014).

Isolat penghasil giberelin $\mathrm{BC} 7$ dan $\mathrm{BC} 8$ menunjukkan reaksi positif ditandai dengan nekrosis pada daun tembakau, dengan demikian isolat BC7 dan BC8 tidak digunakan untuk uji selanjutnya. Hipersensitif merupakan reaksi inang terhadap adanya serangan patogen. Reaksi

Tabel 4 Kesamaan sekuen gen 16S rRNA isolat BC2 menggunakan BLAST-N

\begin{tabular}{lccc}
\hline \multicolumn{1}{c}{ Nama spesies } & $\begin{array}{c}\text { Homologi } \\
(\mathbf{\%})\end{array}$ & Nilai-harapan & No aksesi \\
\hline Bakterium galur RP8 & 98 & 0.0 & KC514104.1 \\
Bakterium galur S2010 & 98 & 0.0 & KM091643.1 \\
Stenotrophomonas maltophilia galur KF973235 & 98 & 0.0 & KJ548880.1 \\
Stenotrophomonas maltophilia galur DZSG-6 & 98 & 0.0 & KC4973235.1 \\
Stenotrophomonas maltophilia galur KC849451 & 98 & 0.0 & KF839451.1 \\
\hline
\end{tabular}




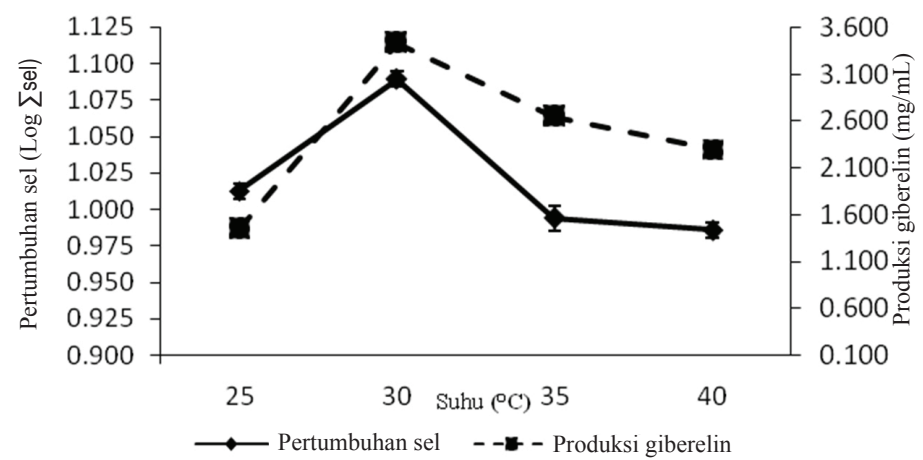

Gambar 5. Pertumbuhan sel dan produksi giberelin isolat BC2 pada suhu yang berbeda.

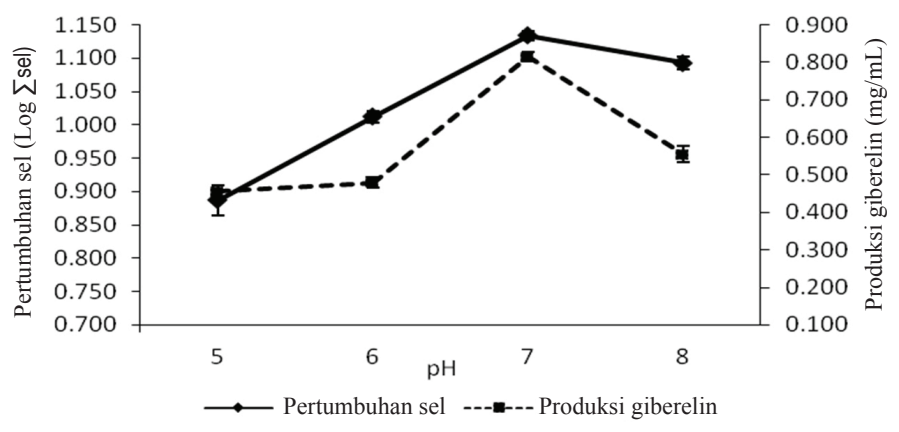

Gambar 6 Pertumbuhan sel dan produksi giberelin isolat BC2 pada berbagai $\mathrm{pH}$.

ini biasanya menyebabkan kematian sebagian sel inang yang bertujuan untuk menghambat pertumbuhan patogen (Lindsay et al. 1993).

Hasil identifikasi molekuler menunjukkan bahwa isolat BC2 kekerabatannya dekat dengan Stenotrophomonas maltophilia dengan tingkat kesamaaan 98\%(Gambar4). Stenotrophomonas maltophilia adalah nama baru dari Pseudomonas maltophilia, bakteri bentuk batang, aerob, Gram negatif, nonpatogen pada tanaman (Palleroni

Tabel 5 Pertumbuhan sel dan produksi isolat $\mathrm{BC} 2$ giberelin pada suhu $30^{\circ} \mathrm{C}$ dan $\mathrm{pH} 7$ dengan kondisi terang dan gelap.

\begin{tabular}{lcc}
\hline Kondisi inkubasi & $\begin{array}{l}\text { Pertumbuhan sel Giberelin } \\
(\mathrm{mg} \text { mL-1) }\end{array}$ \\
\hline Terang & 1.025 & 1.248 \\
Gelap & $1.118^{*}$ & $1.848^{*}$ \\
\hline Tanda $(*)$ berbeda nyata pada uji t $(\alpha=5 \%)$
\end{tabular}

\& Bradbury 1993). Pseudomonas sp. bersifat katalase dan oksidase positif, mengakumulasi $\beta$-polihidroksi butirat sebagai sumber karbon, kemoorganotrof (Arruda et al. 2013) dan memiliki kandungan GC tinggi berkisar 58-68 \% (Broun-Howland et al. 1992).

Pengaruh suhu inkubasi media tumbuh terhadap pertumbuhan sel dan produksi giberelin isolat $\mathrm{BC} 2$ menunjukkan bahwa, pada suhu $25^{\circ} \mathrm{C}$ pertumbuhan sel dan produksi giberelin terendah, sedangkan pada suhu $30^{\circ} \mathrm{C}$ pertumbuhan sel dan produksi giberelin tertinggi. Hal ini ditunjukkan dengan peningkatan jumlah sel dan produksi giberelin pada media pertumbuhan (Gambar 5). Hasil penelitian Karakoc \& Aksos (2006) dan Shruti et al. (2013) mendapatkan suhu optimum untuk pertumbuhan sel dan produksi giberelin isolat Pseudomonas sp. pada suhu $30^{\circ} \mathrm{C}$. 
Pertumbuhan sel dan produksi giberelin isolat $\mathrm{BC} 2$ dipengaruhi oleh $\mathrm{pH}$ media (Gambar 6). Perlakuan pH 5 pada media pertumbuhan menyebabkan pertumbuhan sel dan produksi giberelin isolat $\mathrm{BC} 2$ terendah, sedangkan pada pH 7 pertumbuhan sel dan produksi giberelin tertinggi. Pertumbuhan sel dan produksi giberelin Pseudomonas sp. Juga optimum pada media tumbuh dengan pH 7 (Karakoc \& Akzos 2006).

Pertumbuhan sel dan produksi giberelin isolat $\mathrm{BC} 2$ pada suhu inkubasi $30^{\circ} \mathrm{C}, \mathrm{pH} 7$ dan kondisi cahaya gelap menghasilkan pertumbuhan sel dan produksi giberelin yang lebih tinggi dibandingkan dengan kondisi cahaya terang (Tabel 5). Cahaya dapat menghambat biosintesis giberelin (Karakoc \& Aksoz 2006; Bomke \& Tudzynki 2009; Kang et al. 2015).

Tanah sampel rizosfer akar pohon keruing (Dipterocarpus sp.) di hutan penelitian Carita, Kabupaten Pandeglang Banten menghasilkan 8 isolat rizobakteri penghasil giberelin. Isolat BC2 menghasilkan giberelin tertinggi $(0.897 \mathrm{mg}$ $\mathrm{mL}^{-1}$ ) dan bersifat nonpatogen pada tanaman. Isolat BC2 mempunyai kemiripan $98 \%$ dengan Stenotrophomonas maltophilia KC849451. Pertumbuhan sel isolat $\mathrm{BC} 2$ dan produksi giberelin optimum pada suhu $30^{\circ} \mathrm{C}, \mathrm{pH} 7$ dan kondisi cahaya gelap. Dari hasil penelitian ini, isolat $\mathrm{BC} 2$ berpotensi untuk digunakan sebagai pupuk hayati.

\section{UCAPAN TERIMA KASIH}

\section{Terima kasih kepada DP2M DIKTI} Kementerian Riset dan Pendidikan Tinggi Republik Indonesia yang telah membiayai penelitian ini atas nama Hadi Susilo No kontrak: 0166/E5.1/PE/15 pada tahun 2015.

\section{DAFTAR PUSTAKA}

Ahmad F, Ahmad I, Khan MS. 2008. Scr eening of free-living rhizosphere bacteria for their multiple plant growth promoting activities. Microbiol Res. 163:173-181.

Altschul SF, Madden TL, Schaffer AA, Zhang J, Miller W. 1997. Gapped BLAST and PSI-BLAST: a new generation of protein database search programs. Nucleic Acids Res. 25:3389-3402.

Arruda L, Beneduzi A, Martins A, Lisboa B, Lopes C, Bertolo F, Passaglia LMP, Vargas LK. 2013. Screening of rhizobacteria isolated from maize (Zea mays L.) in Rio Grande do Sul State (South Brazil) and analysis of their potential to improve plant growth. Appl Soil Ecol. 63: 15-22.

Atzorn R, Crozier A, Wheeler C, Sandberg G. 1998. Production of gibberellin and indole 3-acetic acid by Rhizobium phasseoli in relation to nodulation of Phaseolus vulgaris roots. Planta. 175(9):532-538.

Bandelier S, Renaud R. 1997. Production of gibberellic acid by fed-batch solid state fermentation in aseptic pilot scale reactor. Proc Biochem. 32(4):141-145.

Bottini R, Fulchieri M, Pearce D, Pharis RP. 1989. Identification of gibberellin A1, A3, and isoA3, in culture of Azospirillium lipoferum. Plant Physiol. 90(7):45-47.

Bomke C, Tudzynki B. 2009. Diversity, regulation and evolution of the gibberellins biosynthetic pathway in fungi compared to plants and bacteria. Phytochemistry. 70(9):1876.

Broeckling CD, Broz AK, Bergelson J, Manter DK, Vivanco JM. 2008. Root exudates regulate soil fungal community composition and diversity. Appl Environ Microbiol. 18(8):738-744.

Broun-Howland EB, Danielsen SA, Niezwicki-Bouer SA. 1992. Development of rapid method for detecting bacterial cell in situ using 16S rRNA targeted probes. Biotechnique. 13(7):928-933.

Fernie AR, Willmitzer L. 2001. Molecular and biochemical triggers of potato tuber development. Plant Physiol. 127(12):14591465. 
Gunes A, Turan M, Gulluce M, Sahin F. 2013. Nutritional content analysis of plant growthpromoting rhizobacteria species. Eur $J$ Soil Biol. 60:88-97.

Goldberg-Moeller R, Shalom L, Shlizerman L, Samuels S, Zur N, Ophir R, Blumwald E, Sadka A. 2013. Effect of gibberellins treatment during flowering induction period on global gene expression and the transcription of flowering-control genes in Citrus buds. Plant Sci. 198:46-57.

Gomi K, Matsuoka M. 2003. Gibberellin signaling pathway. Curr Opin Plant Biol. 6(4): 489493.

Hyde DK, Aung S, Jeewon R, Pointing BS. 2009. Diversity and abundance of nematodetrapping fungi from decaying litter in terrestrial freshwater and mangrove habitats. J Biodivers Conserv. 18:1695-1714.

Karakoc S, Aksoz N. 2006. Some optimal cultural parameter for gibberellic acid biosynthesis by Pseudomonas sp. Turk J Biol. 30(7):8185.

Kang SM, Khan AL, Waqas M, You YH, Haamayun M, Joo GJ, Shahzad R, Choi KS, Lee IJ. 2015. Gibberellin-producing Serratia nematodiphila PEJ1011 ameliorates low temperature stress in Capsicum annum $L$. Eur J Soil Biol. 30:1-9.

Kumar A, Maurya BR, Raghuwanshi R. 2014. Isolation and characterization of PGPR and their effect on growth, yield and nutrient content in wheat (Triticum aesticum L.). Biocat agri Biotech. 3:121-128.

Lebuhn M, Heulin T, Hartman A. 1997. Production of auxin and other indolic and phenolic compounds by Phaenibacillus polymixa strains isolated from different proximity to plant root. FEMS Microbiol Ecol. 22:325334.

Lindsay WP, Lamb CJ, Dixon RA. 1993. Microbial recognition and activation of plant defence system. Trends Microbiol. 5(1):181-187.

MacMillan J. 2002. Occurence of gibberellins in vascular plants, fungi, and bacteria. $J$ Plant Growth Reg. 20(6):387-443.

Marchesi JR, Sato T, Weightman AJ, Martin TA, Fry JC, Hiom SJ, Wade WG. 1998. Design and evaluation of useful bacterium-specific PCR primer that amplify genes coding for bacterial 16S rRNA. Appl Environ Microbiol. 64(2):796-799.

Miransari M, Smith D. 2014. Plant hormone and seed germination. Environ Exp Bot. 99:110121.

Palleroni NJ. 1984. Practical Handbook of Microbiology. Edisi ke-2. Baltimore: William \& Wilkin.

Palleroni NJ, Bradbury JF. 1993. Stenotrophomonas, a New bacterial genus for Xanthomonas maltophilia (Hugh 1980). Int J Syst Bacteriol. 43(3): 606-609.

Riberio CM, Cardoso EJBN. 2012. Isolation, selection and characterization of rootassociated growth promoting bacteria in Brazil pine (Araucaria angustifolia). Microbiol Res. 167(10):60-78.

Shruti K, Arun K, Yuvneet R. 2013. Potential plant growth-promoting activity of rhizobacteria Pseudomonas sp. in Oryza sativa. J Nat Prod Plant Resour. 3(4):38-50.

Unyayar S, Topcuoglu SF, Unyayar A. 1996. A modified methods for extraction and identification of indol-3-acetic acid (IAA), gibberellins acid (GA3), abscicid acid (ABA) and zeatin product by Phanerochate chrysosporium. Bulg J Plant Physiol. 22(34):105-110.

VannesteJL, PaulinJP, ExpertD. 1990. Bacteriophage as a genetic tool to study Erwinia amylovora pathogenicity and hypersensitive reaction on tobacco. J Bacteriol. 172(2): 932-941. 